\title{
Long-Term Effects of Delapril Hydrochloride on Procollagen Type III Amino-Terminal Peptide, Left Ventricular Mass and Left Ventricular Function in Hypertensive Patients
}

\author{
Munetoshi Matoba, MD; Takayoshi Asaji, MD*; \\ Shinobu Matsui, MD*; Noboru Takekoshi, MD*
}

\begin{abstract}
The long-term effect of delapril hydrochloride, a non-sulfhydryl angiotensin converting enzyme inhibitor, on serum concentrations of procollagen type III amino-terminal peptide (PIIIP) and left ventricular mass (LVM) and function were investigated in 15 hypertensive patients. Patients were treated with delapril hydrochloride 30 $\mathrm{mg} /$ day po for 12 months. Blood samples and an echocardiogram were obtained before treatment and after 6 and 12 months of treatment. Blood pressure, PIIIP, and LVM significantly decreased associated with an increase in left ventricular fractional shortening and mean systolic and diastolic posterior wall velocity at 6 and 12 months of treatment. Positive correlations between PIIIP and LVM $(\mathrm{r}=0.49, \mathrm{p}<0.005)$ and negative correlations between PIIIP and left ventricular fractional shortening $(r=-0.31, p<0.05)$ were found. Delapril hydrochloride reduced PIIIP and LVM and improved cardiac function in hypertensive patients. (Jpn Circ J 1998; 62: 900-902)
\end{abstract}

Key Words: Delapril hydrochloride; Left ventricular mass; Procollagen type III amino-terminal peptide

$\mathbf{L}$ eft ventricular hypertrophy (LVH) is a major hazardous cardiovascular complication in patients with hypertension.,2 The development of LVH depends not only on the renin-angiotensin system generating angiotensin II, 3 but also on the mechanical stress, which activates the protein kinase cascade of phosphorylation in cardiac myocytes. The goal of antihypertensive therapy should be prevention and regression of $\mathrm{LVH}$. It is reported that angiotensin converting enzyme (ACE) inhibitors are more effective than $\beta$-blockers, calcium antagonists, and diuretics in reducing left ventricular mass (LVM) 5 We therefore assessed the clinical effect of delapril hydrochloride (an ACE inhibitor) ${ }^{6}$ from the viewpoint of echocardiographically determined cardiac function and $\mathrm{LVH}$, as well as the serum concentrations of procollagen type III aminoterminal peptide (PIII) as reflected in the production of collagen type III.

\section{Methods}

\section{Patient Selection}

Fifteen hypertensive patients with LVH (10 men and 5 women, mean age 77.2 \pm 7.5 years) were entered in the study. Patients were previously untreated with hypertensive drugs or had discontinued the use of these drugs for at least 4 weeks prior. Patients with hyperglycemia, liver dysfunction or pulmonary fibrosis were excluded. The 2 criteria of LVH were an interventricular septal thickness (IVST) of more than $10 \mathrm{~mm}$ and left ventricular posterior wall thickness (LVPWT) of more than $10 \mathrm{~mm}$ as measured by echocardiography. All study patients complied with these criteria.

(Received June 30, 1998; revised manuscript received August 20, 1998; accepted August 21, 1998)

Department of Internal Medicine, Matoba Hospital and $*$ Department of Cardiology, Kanazawa Medical University, Kanazawa, Japan Mailing address: Munetoshi Matoba, MD, 2-1-1 Miroku-machi, Kanazawa-shi, Ishikawa-ken 920-3115, Japan

\section{Study Protocol}

All patients were treated with an ACE inhibitor (delapril hydrochloride, $30 \mathrm{mg}$ /day po) for 12 months. To evaluate the clinical effect of delapril hydrochloride, blood pressure (BP) and heart rate were measured in a supine position before administration of delapril hydrochloride and then after 6 and 12 months of administration. Blood samples were obtained from each patient. Plasma renin activity (PRA) and concentrations of serum atrial natriuretic peptide (ANP) and serum PIIIP were measured by radioimmunoassay before administration and again after 6 and 12 months of taking the drug. The normal serum concentration of PIIIP, which was $0.40 \pm 0.13 \mathrm{U} / \mathrm{ml}(0.25-0.70 \mathrm{U} / \mathrm{ml})$, was obtained from 24 normal volunteers (aged 20-80 years).

Table 1 Changes in Clinical Data Before and After Treatment With Delapril Hydrochloride

\begin{tabular}{|c|c|c|c|}
\hline & Before & After 6 months & After 12 months \\
\hline Systolic BP (mmHg) & $167.5 \pm 11.2$ & $138.3 \pm 17.5 * * *$ & $129.4 \pm 17.4 * * *$ \\
\hline Diastolic BP $(\mathrm{mmHg})$ & $91.7 \pm 8.7$ & $75.5 \pm 8.0^{* * *}$ & $71.9 \pm 9.4 * * *$ \\
\hline Heart rate (beats/min) & $80.0 \pm 10.7$ & $75.9 \pm 12.3$ & $79.3 \pm 10.3$ \\
\hline $\operatorname{IVST}(\mathrm{mm})$ & $17.1 \pm 4.5$ & $13.9 \pm 2.7 * *$ & $13.5 \pm 3.1 * *$ \\
\hline LVPWT (mm) & $11.6 \pm 1.6$ & $10.6 \pm 1.5^{* *}$ & $9.6 \pm 1.5 * *$ \\
\hline$L V M(g)$ & $336.4 \pm 92.3$ & $264.4 \pm 60.3 *$ & $213.3 \pm 62.1 * * * \dot{*}$ \\
\hline $\operatorname{LVFS}(\%)$ & $29.9 \pm 7.2$ & $34.0 \pm 7.6^{* *}$ & $39.9 \pm 12.8^{* \dagger}$ \\
\hline meanVcf $(\mathrm{circ} / \mathrm{sec})$ & $1.18 \pm 0.34$ & $1.22 \pm 0.34$ & $1.42 \pm 0.59$ \\
\hline$M P W V s(\mathrm{~mm} / \mathrm{sec})$ & $42.8 \pm 13.9$ & $52.3 \pm 14.7$ & $58.4 \pm 16.6^{*}$ \\
\hline$M P W V d(\mathrm{~mm} / \mathrm{sec})$ & $63.8 \pm 22.0$ & $69.0 \pm 22.4$ & $81.3 \pm 19.4^{* \dot{\gamma}}$ \\
\hline$P I I I P(U / m l)$ & $1.05 \pm 0.26$ & $0.85 \pm 0.21 * *$ & $0.80 \pm 0.22 * *$ \\
\hline $\operatorname{PRA}\left(n g \mathrm{ml}^{-1} h^{-1}\right)$ & $2.09 \pm 1.60$ & $2.40 \pm 1.97$ & $1.92 \pm 1.78$ \\
\hline$A N P(p g / m l)$ & $24.7 \pm 20.3$ & $31.7 \pm 17.3$ & $21.0 \pm 11.7$ \\
\hline
\end{tabular}

IVST, intraventricular septal thickness; LVPWT, LV posterior wall thickness; LVM, left ventricular mass; LVFS, LV fractional shortening; $M P W V$ s, mean systolic posterior wall velocity; MPWVd, mean diastolic PWV; PIIIP, procollagen type III amino-terminal peptide; PRA, plasma renin activity; $A N P$, atrial natriuretic peptide. ${ }^{*} p<0.05, * * p<0.01, * * * p<0.001,{ }^{t} p<0.05$. 

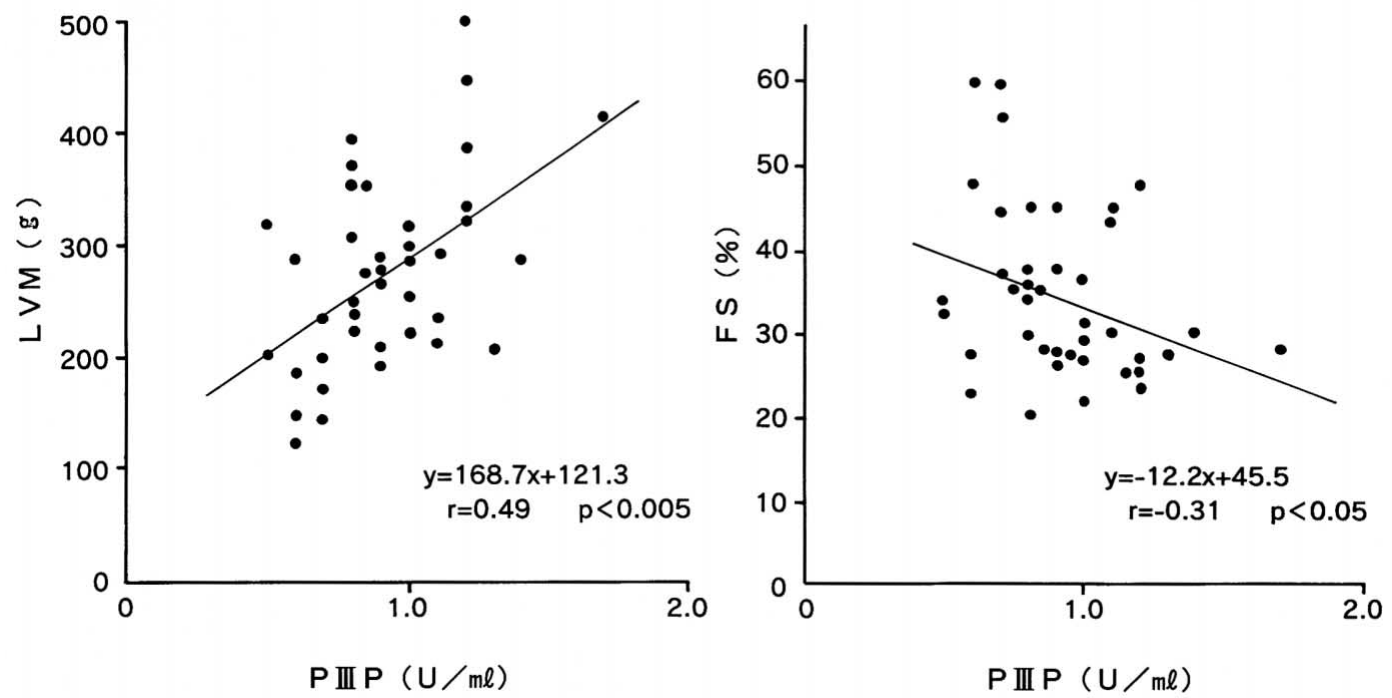

Fig 1. Relationship between serum procollagen type III amino-terminal peptide (PIIIP) concentrations and left ventricular mass (LVM) or left ventricular fractional shortening (LVFS).

M-mode and 2-dimensional echocardiograms were recorded in each patient. Left ventricular fractional shortening (LVFS) and meanVcf were calculated. LVM was calculated using the Devereux formula? Mean systolic posterior wall velocity (MPWVs) and mean diastolic posterior wall velocity (MPWVd) were calculated by the methods of Fogelman et $\mathrm{al}^{8}$ and Yoshikawa et al?

\section{Statistical Analysis}

Differences between the mean values obtained before and after the administration of delapril hydrochloride were analyzed using paired $t$ tests, and $\mathrm{p}<0.05$ was considered statistically significant. The correlation between distributed variables was tested by univariate analysis. Data are expressed as the mean \pm standard deviation.

\section{Results}

\section{Hemodynamic Effects}

Systolic BP significantly decreased from $167.5 \pm 11.2$ $\mathrm{mmHg}$ before treatment to $138.3 \pm 17.5 \mathrm{mmHg}$ at 6 months of treatment $(\mathrm{p}<0.001)$ and to $129.4 \pm 17.4 \mathrm{mmHg}$ at 12 months of treatment $(p<0.001)$. Diastolic BP also significantly decreased. No significant change was observed in heart rate before and after administration of delapril hydrochloride (Table 1). Systolic and diastolic BP achieved the therapeutical goal after the 6-month period of treatment.

\section{Parameters in the Echocardiogram}

IVST and LVPWT significantly diminished from $17.1 \pm 4.5 \mathrm{~mm}$ and $11.6 \pm 1.6 \mathrm{~mm}$ before treatment to $13.9 \pm 2.7 \mathrm{~mm}$ and $10.6 \pm 1.5 \mathrm{~mm}$ at 6 months of treatment $(p<0.01$ and $p<0.01$, respectively). Twelve months after treatment, IVST and LVPWT had both significantly diminished. LVM was significantly decreased [before treatment, $336.4 \pm 92.3 \mathrm{~g}$; at 6 months, $264.4 \pm 60.3 \mathrm{~g}(\mathrm{p}<0.05)$; and at 12 months, $213.3 \pm 62.1 \mathrm{~g}(\mathrm{p}<0.001)]$. LVFS significantly increased from $29.9 \pm 7.2 \%$ before treatment to $34.0 \pm 7.6 \%$ at 6 months $(\mathrm{p}<0.01)$ and to $39.9 \pm 12.8 \%$ at 12 months $(\mathrm{p}<0.05)$. The meanVcf did not change. MPWVs and MPWVd were significantly increased from $42.8 \pm 13.9$ $\mathrm{mm} / \mathrm{s}$ and $63.8 \pm 22.0 \mathrm{~mm} / \mathrm{s}$ to $58.4 \pm 16.6 \mathrm{~mm} / \mathrm{s}(\mathrm{p}<0.05)$ and $81.3 \pm 19.4 \mathrm{~mm} / \mathrm{s}(\mathrm{p}<0.05)$ at 12 months, respectively. In all patients LVH regressed with an improvement in cardiac function and left ventricular wall motion after treatment with delapril hydrochloride (Table 1).

\section{Biochemical Variables}

Serum PIIIP concentrations were significantly diminished from $1.05 \pm 0.26 \mathrm{U} / \mathrm{ml}$ before treatment to $0.85 \pm 0.21$ $\mathrm{U} / \mathrm{ml}(\mathrm{p}<0.01)$ at 6 months of treatment with delapril hydrochloride and to $0.80 \pm 0.22 \mathrm{U} / \mathrm{ml}(\mathrm{p}<0.01)$ at 12 months. Fig 1 shows the relationship between serum PIIIP concentrations and LVM or LVFS. There were significant positive correlations between PIIIP and LVM ( $\mathrm{r}=0.49$, $\mathrm{p}<0.005$ ), and negative correlations between PIIIP and LVFS $(r=-0.31, p<0.05)$. No significant changes in either PRA or ANP were measured before or after treatment (Table 1).

\section{Discussion}

It has been reported that serum PIIIP is a useful marker of fibrogenesis $!^{10}$ The major components of the cardiac interstitium are fibrillar collagens type I and III!11,12 The fibrillar collagens form a network of structual continuum in the myocardium. PIIIP is an extension peptide of the procollagen type III during the conversion of procollagen type III to collagen type III. Serum concentrations of PIIIP $(1.05 \pm 0.26 \mathrm{U} / \mathrm{ml})$ in hypertensive patients in this study were higher compared with the normal serum range of $0.25-0.7 \mathrm{U} / \mathrm{ml}$. These elevations of serum PIIIP appear to reflect an increase in collagen type III production in the hypertensive heart. Type I and III collagen gene expression is increased during the early evolutionary phase of hypertrophy $!^{3}$ Further experiments show that TGF $\beta 1$ in the myocardium may play an important role in the regulation of collagen biosynthesis and myocardial fibrosis ${ }^{14,15}$ The half-life of collagen decreased to 17 days in the hypertrophic myocardium compared with that of 80-120 days in the normal myocardium. Furthermore, fibroblasts and fibroblast proliferation may also contribute to an elevation in collagen synthesis. This remodeling of collagen structure 
has been reported in hypertension, ${ }^{16,17}$ heart failure, ${ }^{18}$ stunned myocardium ${ }^{19}$ and acute myocardial infarction ${ }^{20}$ In the present study, we excluded hypertensive patients accompanied by liver disease, ${ }^{21}$ lung disease ${ }^{22}$ and diabetes $^{23}$ because they have other causes of the elevation of PIIIP.

ANP is mainly released by overloaded atria. During chronic pressure and volume overload the ventricular myocardium may produce ANP in hypertension. In the present study ANP did not change after improvement of LVH by the ACE inhibitor. The changes in plasma ANP were blunted in this study's patients, which may have contributed to the attenuated natriuretic response. Neurohormonal compensation may occur during long-term administration of delapril hydrochloride. The vascular ACE activity is higher in hypertension. In this study the inhibition of vascular ACE activity by delapril hydrochloride seemed to bring about a reduction in BP, irrespective of the circulating renin-angiotensin system.

Delapril hydrochloride is a non-sulfhydryl ACE inhibitor that has a potent and long-lasting inhibitory effect on plasma and tissue angiotensin converting enzyme ${ }^{24} \mathrm{~A}$ reduction in BP and $\mathrm{LVH}$ was reported in animals with systemic hypertension ${ }^{25,26}$ and in humans with arterial hypertension.7,28 Our data suggest that treatment with delapril hydrochloride normalizes serum PIIIP and LVH in hypertensive patients. A reduction in LVH may be produced by interventricular septum and left ventricular posteror wall thinning caused by a decrease in myocardial collagen. Angiotensin II increases collagen synthesis and inhibits collagenase. Therefore, inhibition of angiotensin II generation with delapril hydrochloride actively removes collagen from the cardiac interstitium. Myocardial stiffness may concurrently improve during the treatment. In this study LVFS was significantly increased at 6 months of treatment, and MPWVs and MPWVd were significantly increased at 12 months of treatment as compared with before treatment. This increase of left ventricular wall motion implies an improvement of systolic and diastolic function. The restoration of the fibrillar collagen network in the myocardium accounts for an improvement in left ventricular dysfunction.

In summary, an increase in serum concentration of PIIIP indicates that collagen type III synthesis increases in hypertensive patients. Delapril hydrochloride significantly reduced serum PIIIP, BP and LVM with a significant improvement in left ventricular function.

\section{References}

1. Levy D, Garrison RJ, Savage DD, Kannel WB, Castelli WP: Prognostic implications of echocardiographically determined left ventricular mass in the Framingham heart study. N Engl J Med 1990; 322: $1561-1566$

2. Koren MJ, Devereux RB, Casale PN, Savage DD, Laragh JH: Relation of left ventricular mass and geometry to morbidity and mortality in uncomplicated essential hypertension. Ann Intern Med 1991; 114: 345-352

3. Weber KT, Brilla CG: Pathological hypertrophy and cardiac interstitium: fibrosis and renin-angiotensin-aldosterone system. Circulation 1991; 83: $1849-1865$

4. Yamazaki T, Komuro I, Kudoh S, Zou Y, Shiojima I, Mizuno T, et al: Mechanical stress activates protein kinase cascade of phosphorylation in neonatal rat cardiac myocytes. J Clin Invest 1995; 96: $438-$ 446

5. Dahlöf B, Pennert K, Hansson L: Reversal of left ventricular hypertrophy in hypertensive patients: a metaanalysis of 109 treatment studies. Am J Hypertens 1992; 5: 95-110

6. Inada Y, Tanabe M, Shibouta Y, Kawazoe K, Nishikawa K, Kikuchi S: Antihypertensive action of a non-sulfhydryl angiotensin converting enzyme inhibitor (CV-3317) in various hypertensive models. Jpn J Pharmacol 1986; 42: 1-8

7. Devereux RB, Reichek N: Echocardiographic determination of left ventricular mass in man. Circulation 1977; 55: 613-618

8. Fogelman AM, Abbasi AS, Pearce ML, Kattus AA: Echocardiographic study of the abnormal motion of the posterior left ventricular wall during angina pectoris. Circulation 1972; 46: 905-913

9. Yoshida K, Akasaka T, Maeda K: Evaluation of cardiac function. In: Yoshikawa J, editor. Clinical echocardiography. Tokyo: Bunkodo, 1991: 218

10. Risteli L, Risteli J: Noninvasive methods for detection of organ fibrosis. In: Rojkind M, editor. Focus on connective tissue in health and disease. Boca Raton, FL: CRC Press, 1990: 61-98

11. Weber KT, Pick R, Jalil JE, Janicki JS, Carroll E: Patterns of myocardial fibrosis. J Mol Cell Cardiol 1989; 21: 121-131

12. Eghbali M, Blumenfeld OO, Seifter S, Buttrick PM, Leinwand LA, Robinson TF, et al: Localization of type I, III and IV collagen mRNAs in rat heart cells by in situ hybridization. $\mathrm{J} \mathrm{Mol} \mathrm{Cell} \mathrm{Cardiol}$ 1989; 21: $103-113$

13. Chapman D, Weber KT, Eghbali M: Regulation of fibrillar collagen types I and III and basement membrane type IV collagen gene expression in hypertrophied rat myocardium. Circ Res 1990; 67: 787-794

14. Eghbali M, Tomek R, Sukhatme VP, Woods C, Bhambi B: Differential effects of transforming growth factor $\beta 1$ and phorbol myristate acetate on cardiac fibroblasts. Circ Res 1991; 69: 483-490

15. Yoshiyama M, Takeuchi K, Kim S, Hanatani A, Omura T, Toda I, et al: Effect of manidipine hydrochloride, a calcium antagonist, on isoproterenol-induced left ventricular hypertrophy. Jpn Circ J 1998; 62: $47-52$

16. Laviades C, Mayor G, Diez J: Treatment with lisinopril normalizes serum concentrations of procollagen type III amino-terminal peptide in patients with essential hypertension. Am J Hypertens 1994; 7: 52 58

17. Eleftheriades EG, Durand JB, Ferguson AG, Engelmann GL, Jones $\mathrm{SB}$, Samarel AM: Regulation of procollagen metabolism in the pressure-overload rat heart. J Clin Invest 1993; 91: 1113-1122

18. Brilla CG: The cardiac structure-function relationship and the reninangiotensin-aldosterone system in hypertension and heart failure. Curr Opin Cardiol 1994; 9(Suppl 1): S2-S11

19. Charney RH, Takahashi S, Zhao M, Sonnenblick EH, Eng C: Collagen loss in the stunned myocardium. Circulation 1992; 85: $1483-1490$

20. Jensen LT, HØrslev-Petersen K, Toft P, Bentsen KD, Grande P, Simonsen EE, et al: Serum aminoterminal type III procollagen peptide reflects repair after acute myocardial infarction. Circulation 1990; 81: $52-57$

21. Schuppan D: Connective tissue polypeptides in serum as parameters to monitor antifibrotic treatment in hepatic fibrogenesis. J Hepatol 1991; 13(Suppl 3): S17-S25

22. Low RB, Cutroneo KR, Davis GS, Giancola MS: Lavage type III procollagen $\mathrm{N}$-terminal peptides in human pulmonary fibrosis and sarcoidosis. Lab Invest 1983; 48: 755-759

23. Shimizu M, Umeda K, Sugihara N, Yoshio H, Ino H, Takeda R, et al: Collagen remodelling in myocardia of patients with diabetes. J Clin Pathol 1993; 46: 32-36

24. Kono $\mathrm{T}$, Taniguchi A, Imura $\mathrm{H}$ : Effects of a new angiotensin converting enzyme inhibitor, $\mathrm{N}-[\mathrm{N}-\{(\mathrm{S})-1$-ethoxycarbonyl-3-phenylpropyl\}-L-alanyl]-N-(indan-2-yl) glycine hydrochloride (CV-3317) in normal men. Jpn Arch Intern Med 1984; 31: 63-69

25. Takeda N, Iwai T, Tanamura A, Nakamura I, Nagano M: Effects of delapril hydrochloride on the myocardium of spontaneously hypertensive rats. Can J Cardiol 1994; 10: 939-943

26. Tanaka K, Honda M, Kuramochi T, Hashimoto M, Masumura S, Mansoor AM, et al: Different effects of an angiotensin converting enzyme inhibitor and a calcium antagonist on protein metabolism in rats with right ventricular hypertrophy. J Hypertens 1994; 12: $1147-$ 1154

27. Shionoiri H, Yasuda G, Ikeda A, Ohta T, Miyajima E, Kaneko Y: Pharmacokinetics and depressor effect of delapril in patients with essential hypertension. Clin Pharmacol Ther 1987; 41: 74-79

28. Matsuzaki K, Mukai M, Sumimoto T, Murakami E: Effects of ACE inhibitors versus calcium antagonists on left ventricular morphology and function in patients with essential hypertension. Hypertens Res 1997; 20: $7-10$ 